\title{
ISOLASI BAKTERI PENDEGRADASI XILAN DAN MANAN DARI PERAIRAN INDONESIA
}

\section{Isolation of Xylan and Mannan Degrading Bacteria from Indonesian Waters}

\author{
Winda Tasia ${ }^{1 *}$, Rina Zuraida ${ }^{2}$ dan Yopi ${ }^{1}$ \\ ${ }_{1}^{1}$ Pusat Penelitian Bioteknologi, Lembaga IImu Pengetahun Indonesia, \\ JI. Raya Bogor KM 46 Cibinong, Bogor, Jawa Barat, Indonesia. \\ 2 Pusat Penelitian dan Pengembangan Geologi Kelautan, Badan Penelitian dan Pengembangan Energi dan Sumber Daya Mineral, \\ Kementerian Energi dan Sumber Daya Mineral, JI. Dr. Djunjunan 236, Bandung, Jawa Barat, Indonesia \\ ${ }^{*}$ Korespondensi Penulis : winda.tasia@gmail.com \\ Diterima: 10 April 2016; Disetujui: 1 Mei 2016
}

\begin{abstract}
ABSTRAK
Bakteri laut penghasil enzim xilanase dan mananase menyimpan banyak potensi bagi bioteknologi kelautan. Informasi sebarannya juga dapat digunakan untuk memetakan keragaman bakteri laut serta analisis lingkungan perairan Indonesia sehingga pemanfaatannya dapat tepat sasaran. Penelitian ini bertujuan untuk mengisolasi bakteri laut pendegradasi xilan dan manan dari Indonesia. Penapisan kemampuan xilanolitik dan manolitik menggunakan metode Congo red dilakukan pada isolat bakteri yang diisolasi dari Laut Jawa, Selat Makassar, Laut Flores, dan Laut Sawu pada kedalaman 5 dan $20 \mathrm{~m}$. Hasil penelitian menunjukkan bahwa isolat X7517, X1654, dan XM26511 diketahui menghasilkan xilanase dengan kondisi optimal reaksi enzim masing-masing adalah $\mathrm{pH} 9$, $\mathrm{T} 90^{\circ} \mathrm{C}(2,253 \pm 2,075 \mathrm{U} / \mathrm{ml}), \mathrm{pH} 6, \mathrm{~T} 70^{\circ} \mathrm{C}(0,633 \pm 0,082 \mathrm{U} / \mathrm{ml})$, dan $\mathrm{pH} 6, \mathrm{~T} 70^{\circ} \mathrm{C}(2,293 \pm 0,066 \mathrm{U} / \mathrm{ml})$. Ketiganya diketahui memiliki kesamaan genetis dengan Halomonas aquamarina DSM 30161, Alteromonas macleodii NBRC 102226, dan H. meridiana NBRC 15608. Isolat bakteri manolitik L15203 dan L16571 memiliki kesamaan dengan Idiomarina zobellii KMM231, sedangkan isolat L2207 memiliki kesamaan dengan Bacillus sp. MB 71. Ketiga bakteri tersebut memiliki aktivitas mananase optimal pada kondisi alkali, masing-masing pada $\mathrm{pH} 8, \mathrm{~T} 80^{\circ} \mathrm{C} \quad(0,477 \pm 0,024 \mathrm{U} / \mathrm{ml})$ untuk L 15203, $\mathrm{pH} 9$, $\mathrm{T} 90^{\circ} \mathrm{C}(0,476 \pm 0,009 \mathrm{U} / \mathrm{ml})$ untuk $\mathrm{L} 16571$ dan $\mathrm{pH} 9$, T $80^{\circ} \mathrm{C}(0,528 \pm 0,057 \mathrm{U} / \mathrm{ml})$ untuk L2207. Bakteri laut xilanolitik dan manolitik yang berpotensi dalam produksi xilanase dan mananase melimpah di sebagian perairan Indonesia, terutama di perairan yang semakin dekat permukaan laut atau perairan dangkal.
\end{abstract}

KATAKUNCl: bakteri laut Indonesia, xilanase, mananase

\begin{abstract}
Xylanase and mannanase producing marine bacteria are potential to be utilized in marine biotechnology. Information of their distribution is important to determine the biodiversity pattern of marine bacteria and to analyze the aquatic environment in Indonesia, therefore, they can be appropriately utilized. This research aimed to isolate Indonesian marine bacteria for xylan and mannan degradation. Congo red method was employed to screen xylanolytic and mannolytic abilities on bacteria isolated from Java Sea, Makassar Strait, Flores Sea, and Savu Sea in depth of 5 and $20 \mathrm{~m}$. Results of this study showed that isolate $X 7517, X 1654$, and XM26511 produced xylanase with optimal reaction condition at $\mathrm{pH} \mathrm{9,} \mathrm{T} 90^{\circ} \mathrm{C}(2.253 \pm 2.075 \mathrm{U} / \mathrm{ml}), \mathrm{pH} 6, T 70{ }^{\circ} \mathrm{C}(0.633 \pm 0.082 \mathrm{U} / \mathrm{ml})$, and $\mathrm{pH} 6, T 70{ }^{\circ} \mathrm{C}(2.293 \pm 0.066$ $\mathrm{U} / \mathrm{ml}$ ), respectively. They are genetically similar with Halomonas aquamarina DSM 30161, Alteromonas macleodii NBRC 102226, and $\underline{H}$. meridiana NBRC 15608. Manolytic bacteria L15203 and L16571 were similiar with Idiomarina zobellii KKM 231, while isolate L22207 was similiar with Bacillus sp. MB71. They had mannanase activities which work optimally at alkaline condition of $\mathrm{pH} 8, \mathrm{~T} 7^{\circ} \mathrm{C}$ $(0.477 \pm 0,024 \mathrm{U} / \mathrm{ml}), \mathrm{pH} 9, \mathrm{~T} 80^{\circ} \mathrm{C}(0.476 \pm 0,009 \mathrm{U} / \mathrm{ml})$ and $\mathrm{pH} 9, \mathrm{~T} 80^{\circ} \mathrm{C}(0.528 \pm 0,057 \mathrm{U} / \mathrm{ml})$, respectively. Xylanolytic and mannolytic marine bacteria that are potential for xylanase and mannanase production were found abundantly on parts of Indonesian waters particularly at shallow water.
\end{abstract}

KEYWORDS: Indonesian marine bacteria, xylanase, mannanase 


\section{PENDAHULUAN}

Indonesia memiliki bentangan hutan dan perairan seluas 129.425 ribu hektar (BPS, 2015) dengan keragaman dan kelimpahan biota di dalamnya, termasuk bakteri laut. Menurut Sembiring (2015), bakteri laut memiliki peluang untuk dapat dimanfaatkan dalam industri bioteknologi kelautan, seperti untuk memenuhi kebutuhan farmasi, kosmetik, pangan, pakan, dan produk non konsumsi. Penelitian terkait bakteri laut Indonesia untuk kebutuhan bioremediasi (Andriana, Sudiana \& Sembiring 2009; Harwati, Kasai, Kodama, Susilaningsih, \& Watanabe, 2009; Muniarsih, Yopi \& Budiawan 2009; Muniarsih \& Yopi, 2009) dan farmasi (Bahi, 2012; Blunt, Copp, Munro, Northcote, \& Prinsep 2005) cukup banyak dilaporkan. Meskipun demikian, publikasi hasil penelitian mengenai potensi bakteri laut Indonesia sebagai pendegradasi xilan dan manan masih terbatas.

Xilan, xiloglukan, glukomanan, galaktomanan, galaktoglukomanan, dan arabinogalaktan merupakan komponen penyusun hemiselulosa pada dinding sel tanaman, dengan xilan sebagai komponen utama. Pemotongan ikatan $\beta 1,4$ pada xilan dapat dibantu dengan enzim hidrolitik xilanase (EC 3.2.1.x), yang berperan dalam produksi xilosa dan berperan sebagai sumber karbon utama dalam metabolisme sel. Di sisi lain, terdapat enzim hidrolitik mananase (EC 3.2.1.x) yang secara acak memotong ikatan $\beta 1,4$ pada rantai utama glukomanan, galaktomanan, dan galaktoglukomanan (Collins, Gerday \& Feller, 2005; McCleary, 1988). Enzim xilanase dan mananase banyak diaplikasikan dalam kegiatan industri, seperti untuk kebutuhan pakan, pangan, energi, hingga pembuatan kertas (Chen, Ko, Huang \& Guo, 2015; Comfort et al., 2004; Dhawan \& Kaur, 2007; Khasin, Alchanati \& Shoham, 1993).

Beberapa penelitian terkait bakteri laut Indonesia penghasil enzim xilanase dan mananase telah dilaporkan dalam 5 tahun terakhir. Yopi, Djohan dan Ambarsari (2014) mengisolasi bakteri laut Bacillus safensis LBF002 dari Pulau Pari, Kepulauan Seribu, DKI Jakarta untuk menghasilkan enzim mananase. Enzim tersebut berpotensi untuk memproduksi pangan fungsional, manooligosakarida. Selain itu, $B$. safensis LBF002 dapat menghasilkan enzim xilanase yang berpotensi dalam pengurangan limbah jerami padi dan untuk produksi pangan fungsional serta energi (Djohan, Perwitasari \& Yopi, 2016; Rahmani, Robbani, Suparto, \& Yopi, 2014). Hal ini menunjukkan bahwa bakteri laut Indonesia berpotensi dalam menghasilkan enzim xilanase dan mananase untuk industri berbasis bioteknologi kelautan.
Penelitian ini bertujuan untuk mengisolasi dan menggali potensi bakteri laut penghasil enzim xilanase dan mananase untuk kebutuhan industri pangan dan lingkungan. Analisis sebaran bakteri laut pendegradasi xilan dan manan digunakan untuk memetakan keragaman bakteri laut Indonesia sehingga pemanfaatannya dapat tepat sasaran. Informasi ini juga tepat digunakan untuk analisis lingkungan perairan dan biodiversitas laut Indonesia.

\section{BAHAN DAN METODE}

\section{Bahan}

\section{Sampel air laut}

Sampel air laut adalah air laut yang diambil dari 22 titik di Laut Jawa, Selat Makassar, Laut Flores, dan Laut Sawu pada kedalaman 5 dan $20 \mathrm{~m}$. Sampel diambil pada Bulan Agustus 2015 dan disimpan dalam tabung $50 \mathrm{ml}$ pada suhu $4{ }^{\circ} \mathrm{C}$. Lokasi dan waktu pengambilan sampel disajikan pada Tabel 1 .

\section{Media}

Isolasi bakteri laut dilakukan dengan media cair dan padat yang mengandung $0,1 \%$ xilan murni (Sigma)/manan (locust bean gum/LBG) (Sigma), 0,1\% pepton (Bacto), dan 1,5\% agar (Bacto) dalam air laut buatan. Proses penapisan dilakukan dengan media isolasi padat. Enzim diproduksi dengan media cair yang mengandung $0,5 \%$ xilan/manan, $0,1 \%$ pepton, dan $0,1 \%$ ekstrak khamir dalam air laut buatan.

\section{Metode}

\section{Isolasi dan purifikasi isolat bakteri laut}

Isolasi bakteri dilakukan dengan pengenceran bertingkat. Sampel air laut $(0,5 \mathrm{ml})$ ditambahkan ke dalam media isolasi cair $(4,5 \mathrm{ml})$ dan diinkubasi pada suhu $30^{\circ} \mathrm{C}$ dengan kecepatan pengocokan $150 \mathrm{rpm}$. Hasil pengenceran tingkat keempat hingga keenam $\left(10^{-4}-10^{-6}\right)$ diinokulasikan ke media padat (xilan/manan) dalam cawan petri dengan metode tebar (spread plate method). Koloni bakteri dengan morfologi yang berbeda-beda ditumbuhkan terpisah pada media padat untuk mendapatkan koloni tunggal dan disimpan pada suhu $4{ }^{\circ} \mathrm{C}$ sebagai isolat.

\section{Penapisan bakteri pendegradasi xilan dan manan}

Isolat bakteri ditumbuhkan pada media penapisan dengan metode titik (spot plate method) dan diinkubasi selama 3 hari pada suhu $30^{\circ} \mathrm{C}$. Penapisan dilakukan 
Tabel 1. Lokasi dan waktu pengambilan sampel air laut di Laut Jawa, Selat Makassar, Laut Flores, dan Laut Sawu, Indonesia

Table 1. Location and time of sampling at Java Sea, Makassar Strait, Flores Sea, and Savu Sea, Indonesia

\begin{tabular}{|c|c|c|c|c|c|c|}
\hline \multirow[b]{2}{*}{ No } & \multirow[b]{2}{*}{$\begin{array}{l}\text { Kode Sampel/ } \\
\text { Sample Code }\end{array}$} & \multirow[b]{2}{*}{$\begin{array}{c}\text { Tanggal/ } \\
\text { Date }\end{array}$} & \multirow{2}{*}{$\begin{array}{c}\text { Waktu/ } \\
\text { Time } \\
\text { (WIB) }\end{array}$} & \multicolumn{3}{|c|}{ Lokasi/Location } \\
\hline & & & & $\begin{array}{c}\text { Garis lintang/ } \\
\text { Latitude }\end{array}$ & $\begin{array}{l}\text { Garis bujur/ } \\
\text { Longitude }\end{array}$ & Perairan/Sea,Strait \\
\hline 1 & CTD-WS-04 & $5-08-2015$ & $15: 42: 00$ & $-401,005$ & 110,156 & \\
\hline 2 & CTD-WS-07 & $6-08-2015$ & $12: 32: 00$ & $-49,413$ & $1,110,666$ & Laut Jawa/Java Sea \\
\hline 3 & CTD-WS-11 & 7-08-2015 & $22: 16: 00$ & $-504,367$ & $1,128,617$ & \\
\hline 4 & CTD-WS-15 & $9-08-2015$ & $15: 11: 00$ & $-464,263$ & $1,172,403$ & \\
\hline 5 & CTD-WS-16 & $9-08-2015$ & $23: 44: 00$ & $-470,213$ & $1,172,403$ & Selat Makassar/Makassar \\
\hline 6 & CTD-WS-17 & $10-08-2015$ & $13: 16: 00$ & $-481,657$ & $1,188,087$ & Strait \\
\hline 7 & CTD-WS-18 & $10-08-2015$ & $20: 26: 00$ & $-547,154$ & $1,189,387$ & \\
\hline 8 & CTD-WS-18-YOYO-5 & $11-08-2015$ & $15: 57: 00$ & $-54,619$ & $1,189,467$ & \\
\hline 9 & CTD-WS-19 & $12-08-2015$ & $2: 12: 00$ & $-573,579$ & $1,192,194$ & \\
\hline 10 & MAJAFLOTE CTD-WS-20 & $12-08-2015$ & $8: 39: 00$ & $-598,894$ & $1,196,134$ & \\
\hline 11 & MAJAFLOTE CTD-WS-21 & $12-08-2015$ & $16: 23: 00$ & $-638,216$ & $1,198,519$ & \\
\hline 12 & CTD-WS-22 & $13-08-2015$ & $1: 41: 00$ & $-681,383$ & $1,194,306$ & Laut Flores/Flores Sea \\
\hline 13 & MAJAFLOTE CTD-WS-23 & $14-08-2015$ & $7: 11: 00$ & $-721,844$ & $1,189,396$ & \\
\hline 14 & MAJAFLOTE CTD-WS-24 & $14-08-2015$ & $19: 26: 00$ & $-743,464$ & $1,182,045$ & \\
\hline 15 & MAJAFLOTE CTD-WS-25 & $15-08-2015$ & $11: 52: 00$ & $-729,778$ & $1,164,045$ & \\
\hline 16 & MAJAFLOTE CTD-WS-26 & $15-08-2015$ & $19: 34: 00$ & $-728,267$ & 115,599 & \\
\hline 17 & MAJAFLOTE CTD-WS-27 & $19-08-2015$ & $8: 28: 00$ & $-106,668$ & $1,230,391$ & \\
\hline 18 & CTD-WS-28 & $19-08-2015$ & $3: 01: 00$ & $-105,571$ & 122,881 & \\
\hline 19 & CTD-WS-29 & $18-08-2015$ & $22: ! 4: 00$ & $-107,547$ & $1,226,087$ & \\
\hline 20 & MAJAFLOTE CTD-WS-30 & $18-08-2015$ & $19: 50: 00$ & $-107,646$ & $-1,225,339$ & Laut savuluave sea \\
\hline 21 & MAJAFLOTE CTD-WS-31 & $21-08-2015$ & $2: 26: 00$ & $-107,932$ & $1,232,882$ & \\
\hline 22 & MAJAFLOTE CTD-WS-32 & $21-08-2015$ & $23: 45: 00$ & $-108,524$ & $1,232,973$ & \\
\hline
\end{tabular}

dengan pengujian congo red $0,25 \%$ yang dituang ke media penapisan hingga seluruh permukaan media terendam dan didiamkan di suhu ruang selama 30 menit. Media dibilas dengan $\mathrm{NaCl} 1 \mathrm{M}$ selama 15 menit sebanyak 2 kali. Zona bening menunjukkan kemampuan isolat mendegradasi xilan/manan. Asam asetat $5 \%$ dituang ke dalam media penapisan untuk visualisasi zona bening yang lebih baik (Yopi et al., 2007).

\section{Produksi enzim xilanase dan mananase}

Prekultur dengan kerapatan sel 0,2 pada panjang gelombang $660 \mathrm{~nm}$ ditambahkan ke dalam media kultur $(20 \mathrm{ml})$. Kultur diinkubasi selama 3 hari pada suhu 28-30 ${ }^{\circ} \mathrm{C}$ dengan kecepatan kocok $150 \mathrm{rpm}$. Pengambilan sampel dilakukan setiap hari selama 5 hari. Kultur disentrifugasi pada kecepatan $10.000 \mathrm{~g}$ selama 15 menit. Supernatan disimpan sebagai enzim kasar.

\section{Pengujian kualitatif enzim kasar}

Enzim kasar xilanase dan mananase dari hari ke0 hingga hari ke- 5 diteteskan pada media padat yang mengandung xilan/manan $0,1 \%$ sebanyak $2 \mu \mathrm{l}$. Media diikubasi pada suhu $30^{\circ} \mathrm{C}$ selama 3 hari. Pengujian kualitatif dilakukan dengan pewarnaan Congo red $0,25 \%$ dan asam asetat $5 \%$ dengan melihat zona bening yang terbentuk setiap hari selama 5 hari.

\section{Optimasi pH dan suhu enzim xilanase dan mananase}

Nilai $\mathrm{pH}$ dioptimasi pada kisaran $\mathrm{pH}$ 4-10 dengan menggunakan larutan buffer sitrat ( $\mathrm{pH} 4$ dan 5), buffer fosfat ( $\mathrm{pH} 6$ dan 7), dan buffer glisin ( $\mathrm{pH} 8-10)$ sebagai pelarut substrat (xilan/manan). Optimasi suhu dilakukan pada kisaran $30-100{ }^{\circ} \mathrm{C}$. Aktivitas harian enzim xilanase dan mananase (Bailey, Biely, \& Poutanen, 1992) diukur dengan menginkubasi $250 \mu \mathrm{l}$ 
larutan xilan/manan $(0,1 \%)$ dengan $250 \mu$ l sampel enzim selama 15 menit, dilanjutkan dengan pengukuran gula reduksi dengan metode 3,5dinitrosalicylic acid (DNS) (Miller, 1959).

\section{Identifikasi molekuler isolat bakteri laut dengan sebagian gen $16 S$ rDNA}

Isolat bakteri laut terpilih diidentifikasi secara molekuler dengan metode polymerase chain reactive (PCR) koloni menggunakan primer 9F (5' GAGTTTGATCITIGCTCAG 3') dan 1492R (5' TACGGYTACCTTGTTACGACTT 3'). Kit PCR GoTaq (Promega) digunakan untuk mengisolasi sebagian gen 16S rDNA dari koloni isolat. Analisis urutan basa nitrogen dilakukan oleh $1^{\text {st }} B A S E$ Sequencing INT. Program DNA Baser dan BLAST (Anonim, 2016) digunakan untuk mengidentifikasi spesies isolat bakteri.

\section{HASIL DAN BAHASAN}

\section{Hasil Isolasi Bakteri Xilanolitik dan Manolitik}

Dua puluh dua titik lokasi di perairan Indonesia diteliti sampel air lautnya untuk memperoleh bakteri laut potensial dalam menghasilkan enzim xilanase dan mananase. Dari masing-masing titik lokasi, diambil dua sampel air laut, yaitu dari kedalaman 5 dan 20 $\mathrm{m}$. Sebanyak 287 isolat bakteri xilanolitik berhasil diisolasi dari sampel air laut kedalaman $5 \mathrm{~m}$, sedangkan isolat bakteri manolitik sebanyak 333 isolat. Dari kedalaman $20 \mathrm{~m}$ diperoleh lebih sedikit isolat bakteri xilanolitik maupun manolitik, yaitu masing-masing sejumlah 257 dan 280 isolat. Perbandingan jumlah isolat bakteri xilanolitik dan manolitik yang berhasil diisolasi dari laut kedalaman 5 dan 20 m disajikan pada Gambar 1.

Jumlah isolat bakteri yang berhasil diisolasi dari masing-masing titik sampel dapat dilihat pada Tabel 2. Tekanan hidrostatis dan ketersediaan nutrisi dapat menjadi penyebab dari perbedaan hasil isolasi ini. Semakin dalam dari permukaan laut, maka tekanan hidrostatis semakin tinggi dan membatasi jumlah spesies makhluk hidup, termasuk mikroorganisme. Faktor nutrisi di laut juga memengaruhi karena makanan diproduksi di zona eufotik (lapisan air bagian atas dan tembus cahaya). Selain itu, permukaan laut atau laut dangkal juga mendapat nutrisi yang teralirkan dari daratan (Sanders \& Hessler, 1969; Scheffer \& van Nes, 2007).

\section{Hasil Penapisan dan Pengujian Kualitatif Isolat Bakteri Xilanolitik dan Manolitik}

Terdapat 3 isolat bakteri xilanolitik dan 3 isolat bakteri manolitik terpilih hasil pengujian dengan Congo red dan asam asetat. Pewarna Congo red berikatan dengan xilan/manan dan terserap di media sehingga warna media menjadi merah. Berdasarkan hal tersebut, zona bening yang terbentuk di sekitar koloni bakteri menunjukkan bahwa xilan/manan di zona tersebut dapat didegradasi dan dimanfaatkan

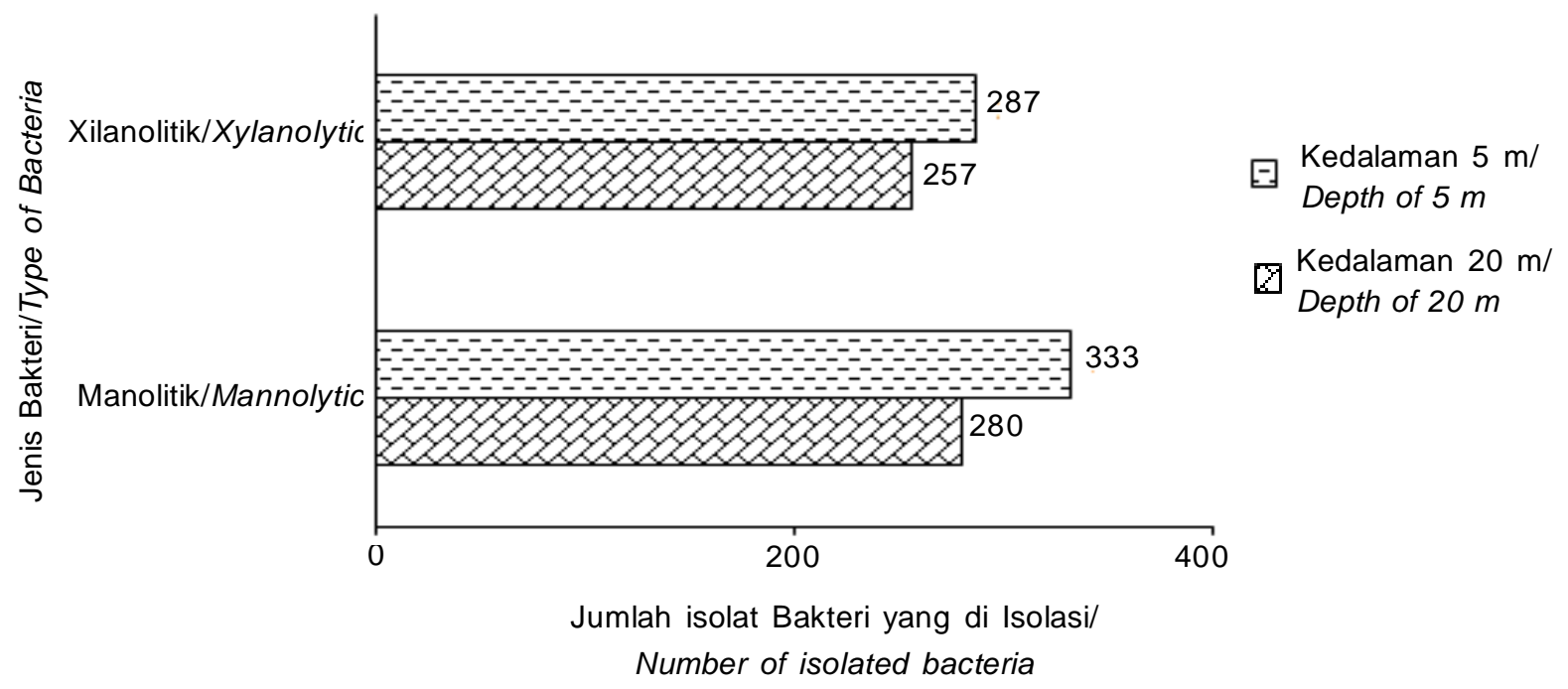

Gambar 1. Perbandingan jumlah isolat bakteri laut xilanolitik dan manolitik yang berhasil diisolasi dari perairan Indonesia pada kedalaman 5 dan $20 \mathrm{~m}$.

Figure 1. Comparison of xylanolytic and mannolytic bacteria isolated from sea of Indonesia at depth of 5 and $20 \mathrm{~m}$. 
Tabel 2. Jumlah jenis isolat bakteri laut pendegradasi xilan dan manan dari 22 titik sampel pada kedalaman 5 dan $20 \mathrm{~m}$.

Table 2. Number of bacteria isolated from 22 sampling site from the depth of 5 and $20 \mathrm{~m}$.

\begin{tabular}{|c|c|c|c|c|}
\hline \multicolumn{3}{|c|}{ Sampel/Sample } & \multicolumn{2}{|c|}{$\begin{array}{c}\text { Jumlah isolat yang diisolasi } / \\
\text { Number of isolates }\end{array}$} \\
\hline $\begin{array}{l}\text { Kode Sampel/ } \\
\text { Sample Code }\end{array}$ & $\begin{array}{l}\text { Lokasi/ } \\
\text { Location }\end{array}$ & $\begin{array}{l}\text { Kedalaman/ } \\
\text { Depth }(m)\end{array}$ & $\begin{array}{l}\text { Xilanolitik/ } \\
\text { Xylanolytic }\end{array}$ & $\begin{array}{c}\text { Manolitik/ } \\
\text { Mannnolytic }\end{array}$ \\
\hline \multirow{2}{*}{ CTD-WS-04 } & & 5 & 4 & 6 \\
\hline & & 20 & 3 & 3 \\
\hline \multirow{2}{*}{ CTD-WS-07 } & Laut Jawa/ & 5 & 20 & 17 \\
\hline & Java Sea & 20 & 1 & 4 \\
\hline \multirow{2}{*}{ CTD-WS-11 } & & 5 & 16 & 19 \\
\hline & & 20 & 2 & 2 \\
\hline \multirow{2}{*}{ CTD-WS-15 } & & 5 & 20 & 20 \\
\hline & & 20 & 2 & 4 \\
\hline \multirow{2}{*}{ CTD-WS-16 } & Selat Makassar/ & 5 & 4 & 5 \\
\hline & Makassar Strait & 20 & 19 & 19 \\
\hline \multirow{2}{*}{ CTD-WS-17 } & & 5 & 25 & 24 \\
\hline & & 20 & 9 & 6 \\
\hline \multirow{2}{*}{ CTD-WS-18 } & & 5 & 12 & 18 \\
\hline & & 20 & 1 & 5 \\
\hline \multirow{2}{*}{ CTD-WS-18-YOYO-5 } & & 5 & 17 & 17 \\
\hline & & 20 & 22 & 21 \\
\hline \multirow{2}{*}{ CTD-WTS-19 } & & 5 & 14 & 18 \\
\hline & & 20 & 10 & 6 \\
\hline \multirow{2}{*}{ MAJAFLOTE CTD-WS-20 } & & 5 & 12 & 16 \\
\hline & & 20 & 12 & 14 \\
\hline \multirow{2}{*}{ MAJAFLOTE CTD-WS-21 } & & 5 & 12 & 16 \\
\hline & Laut Flores/ & 20 & 7 & 12 \\
\hline \multirow{2}{*}{ CTD-WS-22 } & Flores Sea & 5 & 15 & 16 \\
\hline & & 20 & 13 & 9 \\
\hline \multirow{2}{*}{ MAJAFLOTE CTD-WS-23 } & & 5 & 12 & 16 \\
\hline & & 20 & 25 & 23 \\
\hline \multirow{2}{*}{ MAJAFLOTE CTD-WS-24 } & & 5 & 18 & 12 \\
\hline & & 20 & 10 & 22 \\
\hline \multirow{2}{*}{ MAJAFLOTE CTD-WS-25 } & & 5 & 13 & 18 \\
\hline & & 20 & 16 & 17 \\
\hline \multirow{2}{*}{ MAJAFLOTE CTD-WS-26 } & & 5 & 14 & 14 \\
\hline & & 20 & 14 & 12 \\
\hline \multirow{2}{*}{ MAJAFLOTE CTD-WS-27 } & & 5 & 12 & 15 \\
\hline & & 20 & 15 & 19 \\
\hline \multirow{2}{*}{ CTD-WS-28 } & & 5 & 14 & 14 \\
\hline & & 20 & 8 & 15 \\
\hline \multirow{2}{*}{ CTD-WS-29 } & & 5 & 7 & 16 \\
\hline & Laut Sawu/ & 20 & 17 & 18 \\
\hline \multirow{2}{*}{ MAJAFLOTE CTD-WS-30 } & Savu Sea & 5 & 10 & 13 \\
\hline & & 20 & 15 & 12 \\
\hline \multirow{2}{*}{ MAJAFLOTE CTD-WS-31 } & & 5 & 8 & 14 \\
\hline & & 20 & 23 & 20 \\
\hline \multirow{2}{*}{ MAJAFLOTE CTD-WS-32 } & & 5 & 8 & 9 \\
\hline & & 20 & 13 & 17 \\
\hline
\end{tabular}


Isolat bakteri xilanolitik/ Isolates of xylanolytic bacteria
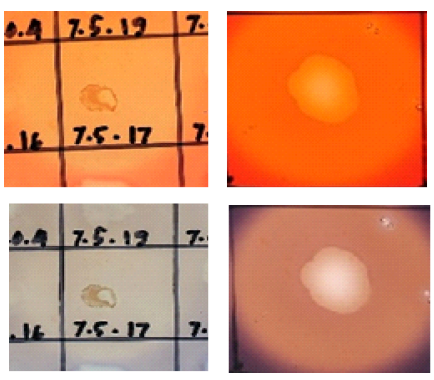

X7517

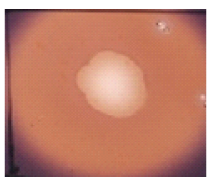

$\mathrm{X} 1654$
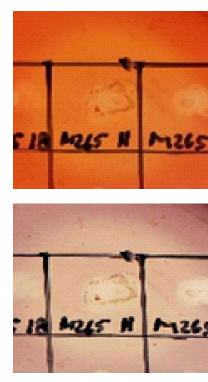

XM26511 (a)
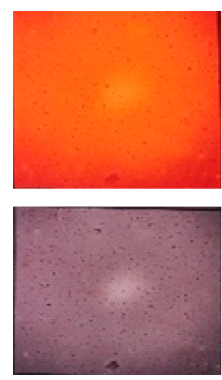

L15203
Isolat bakteri manolitik/ Isolates of mannolytic bacteria
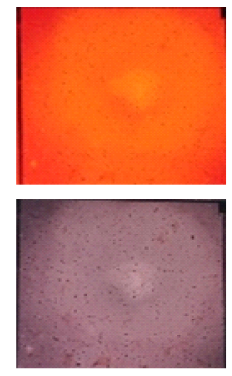

L16571
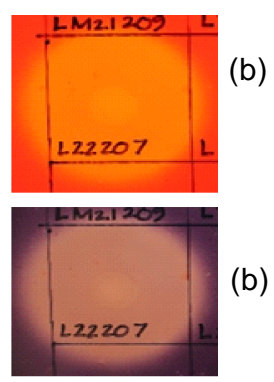

L22207

Gambar 2. Hasil penapisan bakteri xilanolitik dan manolitik dengan pengujian (a) Congo red 0,25\% dan (b) penambahan asam asetat $5 \%$ untuk visualisasi zona bening yang lebih baik.

Figure 2. Screening of xylanolytic and mannolytic bacteria using (a) 0,25\% Congo red method and (b) addition of $5 \%$ acetic acid for better clear zone visualization.

oleh isolat bakteri sebagai sumber karbon (Downie, Hilhorst, \& Bewley, 1994). Hasil penapisan dan pengujian isolat bakteri xilanolitik dan manolitik menggunakan Congo red disajikan pada Gambar 2.

Isolat X7517, X1654, dan XM26511 adalah isolat bakteri laut yang memiliki kemampuan xilanolitik. Isolat-isolat bakteri tersebut diisolasi dari kedalaman $5 \mathrm{~m}$ dari tiga lokasi yang berbeda, masing-masing dari Laut Jawa (CTD-WS-07), Selat Makassar (CTD-
WS-16), dan Laut Flores (MAJAFLOTE-CTD-WS-26). Isolat bakteri manolitik terpilih yaitu L15203 dan L16571, diisolasi dari Selat Makassar, masing-masing dari titik sampel CTD-WS-15 kedalaman $20 \mathrm{~m}$ dan CTD-WS-16 kedalaman $5 \mathrm{~m}$. Isolat bakteri L22207 juga merupakan isolat bakteri manolitik terpilih yang diisolasi dari Laut Flores (CTD-WS-22) pada kedalaman $20 \mathrm{~m}$. Morfologi isolat-isolat terpilih disajikan dalam Gambar 3.

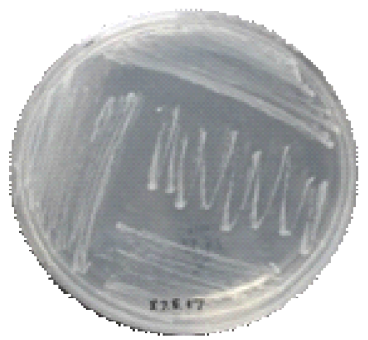

(a)

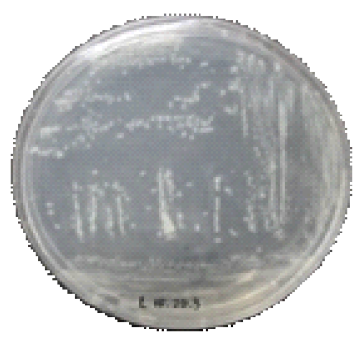

(d)

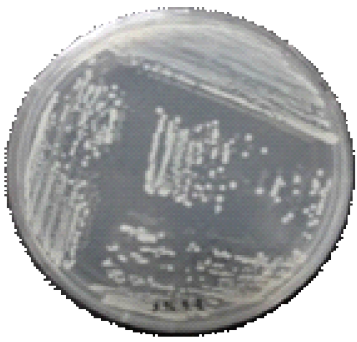

(b)

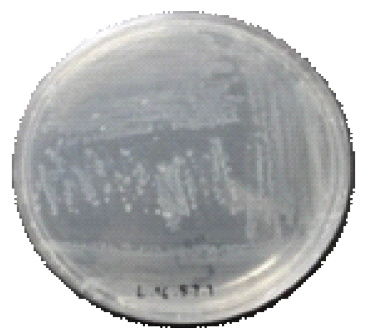

(e)

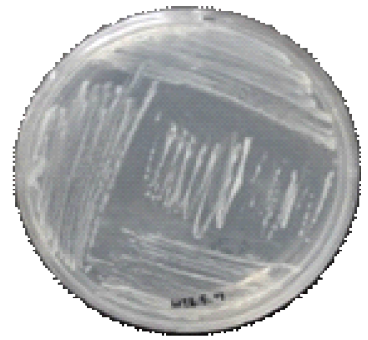

(c)

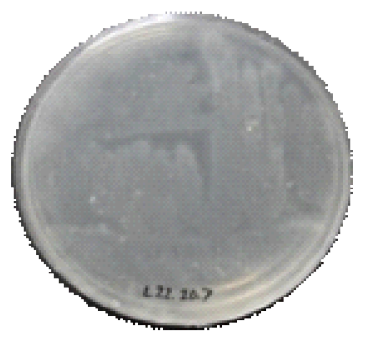

(f)

Keterangan/Note:
(a) Isolat $\mathrm{X} 7517 / \mathrm{X} 7517$ isolate
(b) Isolat $\mathrm{X} 1654 / \mathrm{X} 1654$ isolate
(d) Isolat L15203/ L15203 isolate
(e) Isolat L16571/ L16571 isolate
(c) Isolat XM26511/ XM26511 isolate
(f) Isolat L22207/ L22207 isolate

Gambar 3. Morfologi isolat bakteri terpilih pendegradasi xilan (a, b,c) dan manan (d, e, f).

Figure 3. Morphology of selected bacterial isolates for xylan $(a, b, c)$ and mannan (d, e, f) degradation. 

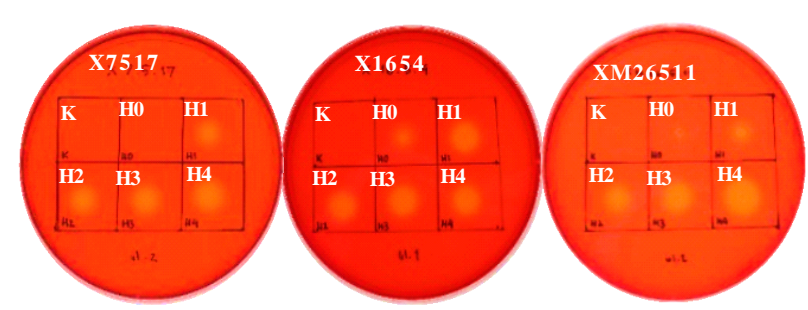

(a)
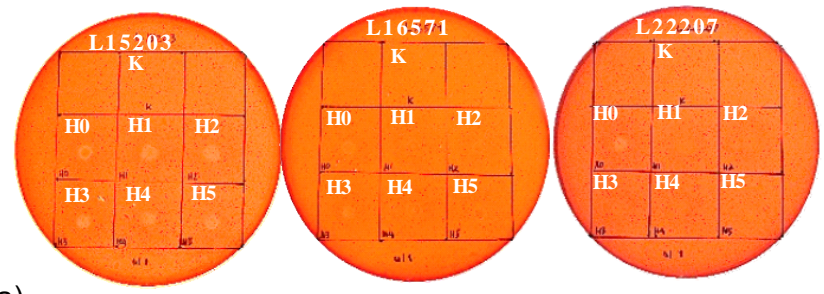

\section{.}
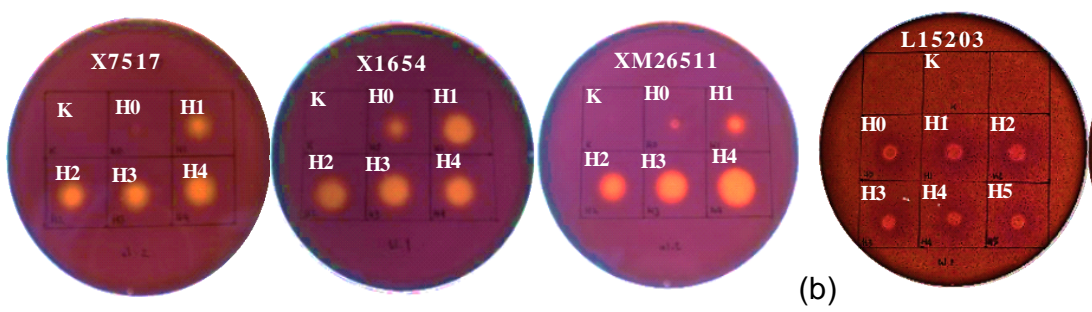

(b)

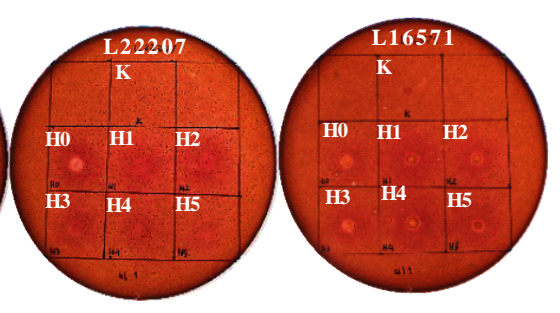

Gambar 4. Pengujian kualitatif aktivitas xilanolitik dan manolitik dengan (a) analisis Congo red $0,25 \%$ dan (b) asam asetat $5 \%$ untuk visualisasi yang lebih baik.

Figure 4. Qualitative assay for xylanolytic and mannolytic activity determination (a) 0,25\%Congo red analysis (b) $5 \%$ acetic acid for better visualization.

Aktivitas enzim kasar xilanase dan mananase tampak dari terbentuknya zona bening pada pengujian kualitatif enzim harian. Enzim xilanase dan mananase yang diproduksi oleh isolat bakteri terakumulasikan setiap hari sehingga zona bening yang terbentuk semakin membesar, seperti pada Gambar 4.

Pengujian dilakukan dengan sampel harian enzim kasar masing-masing isolat dari hari ke- $0(\mathrm{H} 0)$ hingga hari ke-4 $(\mathrm{H} 4)$ dengan kontrol $(\mathrm{K})$ sebagai pembanding untuk mengetahui aktivitas enzim xilanase. Pengujian hingga hari ke-5 (H5) dilakukan pada enzim kasar mananase untuk membandingkan aktivitas enzim mananase dan xilanase secara kualitatif. Hasil menunjukkan bahwa meskipun waktu pengamatan dilakukan lebih lama terhadap aktivitas mananase (5 hari), zona bening yang terbentuk tidak terlihat meningkat sehingga secara kualitatif aktivitas enzim mananase dapat dikatakan lebih kecil dibandingkan dengan aktivitas enzim xilanase. Pengujian aktivitas enzim xilanase dan mananase secara kuantitatif penting dilakukan untuk memastikan hal tersebut.

Zona bening menunjukkan kemampuan enzim kasar dalam mendegradasi xilan murni dan LBG. Enzim kasar xilanase dimungkinkan masih mengandung dua kelas endoxilanase, lima selulase, dan enzim-enzim lain yang terkait (Miao, Li, Xiao, Shen, \& Zhang, 2015). Begitu pula dengan enzim kasar mananase yang mengandung beberapa komponen enzim di dalamnya (Araujo \& Ward, 1990). Mempertimbangkan hal tersebut, langkah purifikasi untuk xilanase dan mananase spesifik yang diinginkan pun banyak dilakukan (Araujo \& Ward; Miao et al.)

\section{Nilai pH dan Suhu Optimal Reaksi Enzim Xilanase dan Mananase}

Xilanase yang diperoleh dari isolat bakteri laut adalah xilanase alkali dan netral. Isolat X7517 menghasilkan xilanase alkali dengan reaksi optimal di $\mathrm{pH}$ 9, sedangkan isolat X1654 optimal di pH 6. Xilanase dari isolat XM26511 memiliki aktivitas optimal di $\mathrm{pH} 6(0,431 \pm 0,007 \mathrm{U} / \mathrm{ml})$, tidak berbeda jauh dengan aktivitas di pH 8, yakni 0,421 $\pm 0,066 \mathrm{U} / \mathrm{ml}$ (Gambar 5). Pada penelitian sebelumnya yang telah dilaporkan, xilanase alkali dari $B$. subtilis yang diisolasi dari muara Vellar, India bekerja optimal di pH 9 dengan aktivitas $128 \mathrm{U} / \mathrm{ml}$ (Annamalai, Thavasi, Jayalakshmi \& Balasubramanian, 2009). B. subtilis XP10 dari air laut di Jeddah, Arab Saudi juga menghasilkan xilanase alkali yang optimal di $\mathrm{pH} 8(2,82 \mathrm{U} / \mathrm{ml})$ (Tork, Aly, Alakilli \& Al-Seeni, 2013), sedangkan Menon, Mody, Keshri, dan Jha (2010) mengisolasi Bacillus pumilis GESF-1 dari sedimen pertanian garam yang menghasilkan xylanase optimal di pH 8. Xilanase alkali dimanfaatkan industri pulp dan kertas untuk meningkatkan kualitas kertas (Beg, Kapoor, Mahajan, \& Hoondal, 2001; Thomas, Sindhu \& Pandey, 2013).

Mananase yang diperoleh dari isolat bakteri terpilih adalah mananase alkali. Mananase dari isolat L15203 optimal di pH 8, sedangkan isolat L16571 dan L22207 optimal di pH 9 (Gambar 6). Tidak banyak penelitian yang melaporkan enzim mananase alkali dari bakteri laut, terutama dari perairan Indonesia. Mannanase alkali banyak dilaporkan diproduksi dari Bacillus (Hatada et al., 2005) dan Streptomyces (Yoo et al., 2015; Pradeep et al., 2016), sedangkan Yopi et al. 

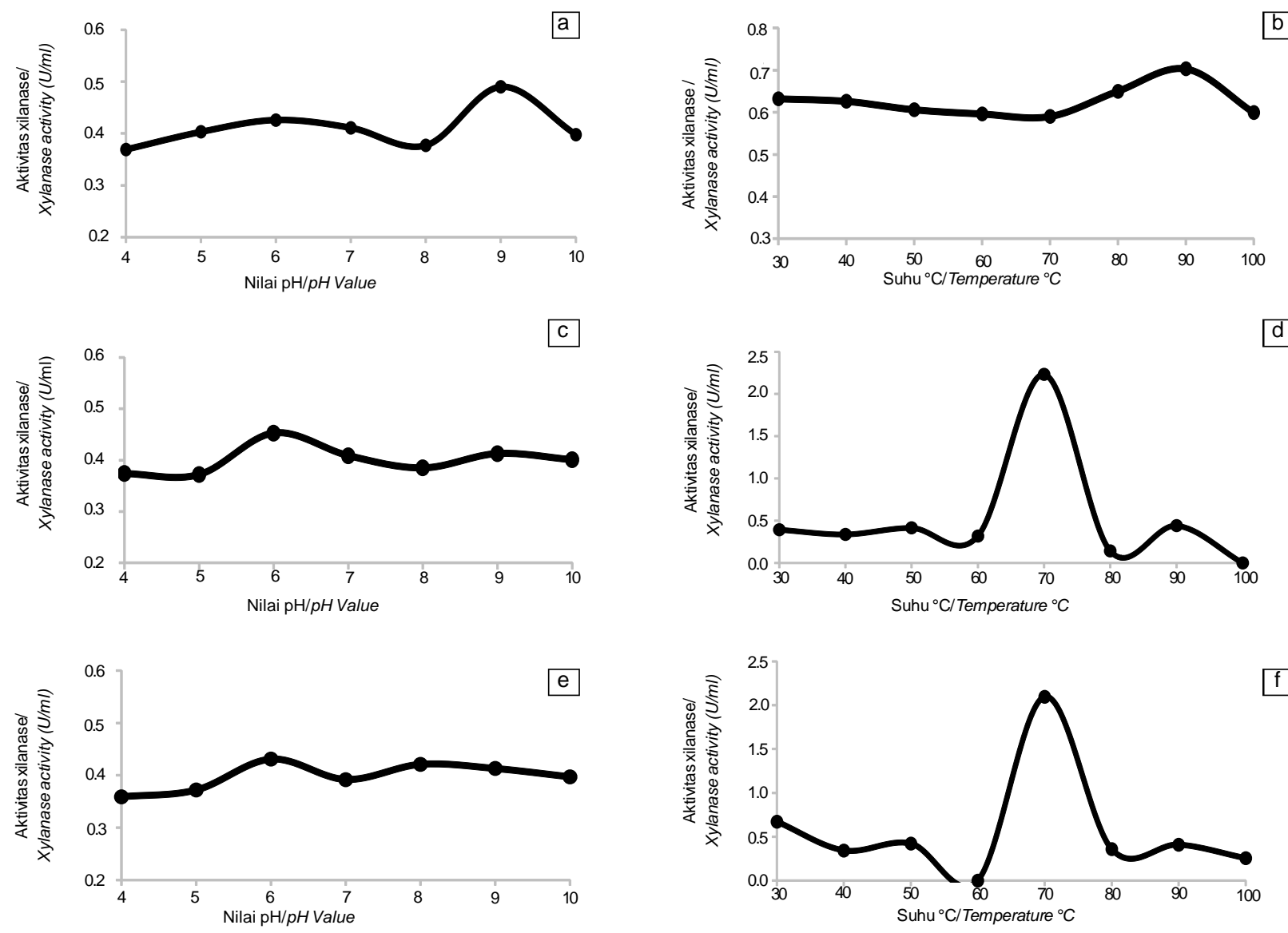

Gambar 5. Optimasi pH dan suhu isolat xilanolitik (a \& b) isolat X7517, (c \& d) isolat X1654 dan (e \& f) isolat XM 26511

Figure 5. Optimization of $\mathrm{pH}$ and temperature of xylanolytic isolates (a \& b) X7517 isolate, (c \& d) X1654 isolate and (e \& f) XM 26511 isolate

(2014) mengisolasi Bacillus manolitik dari air laut di Pulau Pari, DKI Jakarta untuk produksi manooligosakarida. Potensi mananase alkali sangat luas, seperti dimanfaatkan oleh industri deterjen dan kertas karena sebagian besar proses di industri tersebut dilakukan di $\mathrm{pH}$ tinggi (Chauhan, Puri, Sharma, \& Gupta, 2012; Dhawan \& Kaur, 2007; Hatada et al., 2005).

Reaksi xilanase dan mananase dari isolat terpilih optimal pada kisaran suhu $70-90^{\circ} \mathrm{C}$. Xilanase dari isolat X7517 optimal pada suhu $90^{\circ} \mathrm{C}, \mathrm{X} 1654$ dan XM26511 di suhu $70^{\circ} \mathrm{C}$ (Gambar 5). Hal serupa dilaporkan Winterhalter dan Liebl (1995) yang menguji xilanase dari bakteri laut Thermotoga maritima MSB8, optimal pada suhu $92^{\circ} \mathrm{C}$ dan $105^{\circ} \mathrm{C}$. Enzim kasar xilanase dari Geobacillus sp. yang diisolasi dari laut dalam Pasifik Timur pun memiliki karakteristik aktif di suhu $70-90^{\circ} \mathrm{C}$ dan pH 5-10 (Wu, Liu \& Zhang 2006). Karakteristik enzim xilanase ini diperlukan di industri pakan ternak, produksi biofuel, pembuatan bir (Chen et al., 2015), dan industri pulp dan kertas sebagai katalis dalam proses pemutihan (pulp bleaching) (Khasin et al., 1993).

Mananase dari bakteri laut yang stabil di suhu tinggi juga belum banyak dilaporkan. Enzim mananase komersial, Pyrolase 160 dan Pyrolase 200, merupakan mananase yang stabil di suhu tinggi hingga $93^{\circ} \mathrm{C}$ dan dapat dimanfaatkan oleh industri minyak dan gas (Dhawan \& Kaur, 2007). Mananase dari isolat L15203 aktif di suhu $70^{\circ} \mathrm{C}$, sementara dari isolat L16571 dan L22207 optimal di suhu $80^{\circ} \mathrm{C}$ (Gambar 6). Karakteristik serupa dimiliki endo-(1,4)- $\alpha$-mananase dari bakteri laut $R$ hodothermus marinus yang optimal di suhu $85^{\circ} \mathrm{C}$ dan masih terdapat aktivitas hingga suhu $90^{\circ} \mathrm{C}$ (Politz, Krah, Thomsen \& Borriss, 2000). Potensi mananase ini dapat menjadi alternatif pengganti enzim komersial yang digunakan oleh industri minyak dan gas untuk meningkatkan aliran 

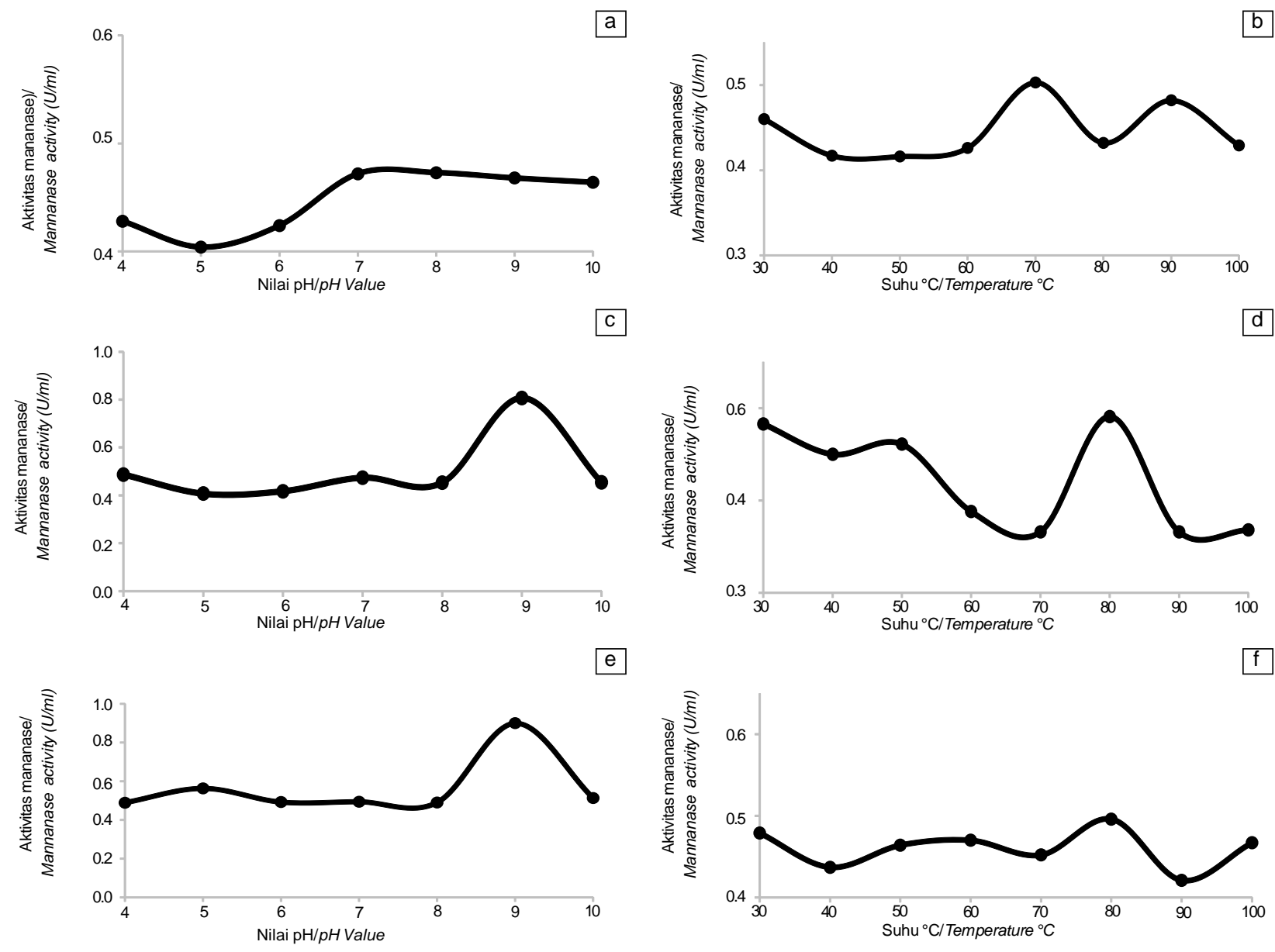

Gambar 6. Optimasi pH dan suhu isolat manolitik (a \& b) isolat L15203, (c \& d) isolat L16571 dan (e \& f) isolat L22207

Figure 6. Optimization of $\mathrm{pH}$ and temperature of mannolytic isolates (a \& b) L15203 isolate, (c \& d) L16571 isolate and (e \& f) L22207 isolate

minyak dan gas selama proses pengeboran (Comfort et al., 2004).

Aktivitas enzim kasar xilanase dan mananase pada isolat terpilih dari hari pertama hingga hari kelima diukur dengan metode DNS. Hasil menunjukkan bahwa waktu optimal aktivitas masing-masing enzim berbedabeda seperti tampak pada Gambar 7. Xilanase dari isolat X7517 optimal di hari pertama dengan aktivitas 2,253 $\pm 2,075 \mathrm{U} / \mathrm{ml}$ dan berangsur-angsur semakin menurun hingga hari kelima. Pola yang serupa ditunjukan oleh xilanase dari isolat XM26511 dengan aktivitas tertinggi 2,293 $\pm 0,066 \mathrm{U} / \mathrm{ml}$ di hari pertama. Xilanase dari isolat X1654 memiliki aktivitas lebih rendah, yaitu $0,633 \pm 0,082 \mathrm{U} / \mathrm{ml}$ pada hari keempat produksi, namun nilai tersebut tidak jauh berbeda dengan aktivitasnya di hari pertama hingga ketiga, maupun di hari kelima.

Aktivitas tertinggi mananase dari isolat $\mathrm{L} 15203$ dan L16571 memiliki nilai yang tidak berbeda jauh, yaitu masing-masing $0,477 \pm 0,024 \mathrm{U} / \mathrm{ml}$ dan $0,476 \pm 0,009$ $\mathrm{U} / \mathrm{ml}$. Meski demikian, keduanya memiliki pola aktivitas enzim yang berbeda (Gambar 7). Aktivitas xilanase dari isolat L15203 tertinggi di hari keempat, sedangkan dari isolat L16571 di hari pertama. Aktivitas mananase dari isolat L22207 lebih tinggi dibandingkan dua mananase lainnya, yaitu $0,528 \pm 0,057 \mathrm{U} / \mathrm{ml}$ di hari kedua produksi.

\section{Identifikasi Isolat Bakteri Xilanolitik dan Manolitik}

Berdasarkan identifikasi sebagian gen 16S rDNA, genus dan spesies masing-masing isolat terpilih dianalisis. Isolat X7517 dan XM26511 teridentifikasi sebagai bakteri Halomonas dengan derajat similaritas sebesar 99\% (Tabel 3). Isolat X7517 memiliki kemiripan genetis dengan Halomonas aquamarina strain DSM 30161 yang sebelumnya dilaporkan oleh Arahal, Ludwig, Schleifer dan Ventosa (2002). Bakteri 

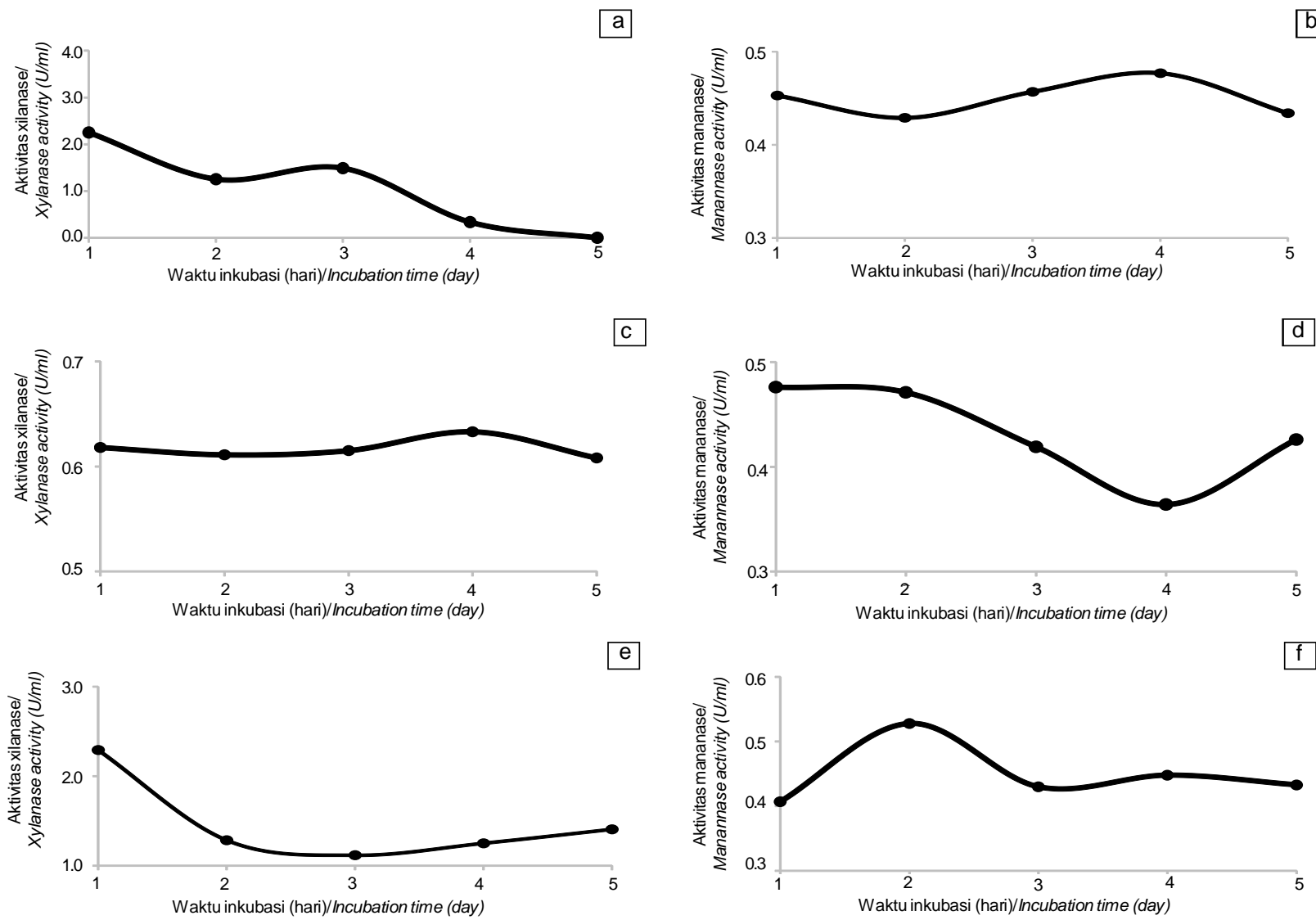

Gambar 7. Waktu optimal aktivitas enzim xilanase dan mananase dari isolat bakteri terpilih berbeda-beda dalam rentang waktu produksi satu hingga lima hari (a) isolat X7517, (b) isolat L15203, (c) isolat X1654, (d) isolat L16571, (e) isolat XM26511, dan (f) isolat L22207.

Figure 7. Different optimal time of xylanase and mannanase activity from selected bacterial isolates on the range of production time from one to five days (a) X7517 isolate, (b) L15203 isolate, (c) X1654 isolate, (d) L16571 isolate, (e) XM26511 isolate, and (f) L22207 isolate.

Tabel 3. Hasil identifikasi molekuler gen 16S rDNA isolat bakteri laut terpilih dengan BLAST

Table 3. Result of molecular identification using $16 S$ rDNA gene on selected marine bacteria using BLAST

\begin{tabular}{|c|c|c|c|c|c|}
\hline No & $\begin{array}{c}\text { Kode Isolat/ } \\
\text { Code of isolate }\end{array}$ & $\begin{array}{c}\text { Kemampuan/ } \\
\text { Ability }\end{array}$ & $\begin{array}{c}\text { Hasil Identifikasi/ } \\
\text { Identification Result }\end{array}$ & $\begin{array}{c}\text { Similaritas/ } \\
\text { Similarity }\end{array}$ & $\begin{array}{c}\text { No. Akses/ } \\
\text { Accession number }\end{array}$ \\
\hline 1 & $X 7517$ & $\begin{array}{l}\text { Xlanolitik/ } \\
\text { Xylanolytic }\end{array}$ & $\begin{array}{c}\text { Halomonas aquamarina } \\
\text { DSM30161 }\end{array}$ & $99 \%$ & NR 042063.1 (Arahal et al., 2002) \\
\hline 2 & X1654 & $\begin{array}{l}\text { Xlanolitik/ } \\
\text { Xylanolytic }\end{array}$ & $\begin{array}{l}\text { Alteromonas macleodii } \\
\text { NBRC } 102226\end{array}$ & $99 \%$ & NR 114053.1 \\
\hline 3 & XV26511 & $\begin{array}{l}\text { Xlanolitik/ } \\
\text { Xylanolytic }\end{array}$ & $\begin{array}{l}\text { Halomonas meridiana } \\
\text { NBRC } 15608\end{array}$ & $99 \%$ & NR 113779.1 \\
\hline 4 & L15203 & $\begin{array}{l}\text { Manolitik/ } \\
\text { Mannolytic }\end{array}$ & $\begin{array}{c}\text { Idiomarina zobellii } \\
\text { KMM231 }\end{array}$ & $99 \%$ & NR 024892.1 (Ivanova et al., 2000) \\
\hline 5 & L16571 & $\begin{array}{l}\text { Manolitik/ } \\
\text { Mannolytic }\end{array}$ & $\begin{array}{l}\text { Idiomarina zobellii } \\
\text { KMM231 }\end{array}$ & $84 \%$ & NR 024892.1 (Ivanova et al., 2000) \\
\hline 6 & L22207 & $\begin{array}{l}\text { Manolitik/ } \\
\text { Mannolytic }\end{array}$ & Bacillus sp. MB 71 & $78 \%$ & AB 518983.1 (Velmurugan et al., 2011) \\
\hline
\end{tabular}


H. aquamarina DSM 30161 merupakan koleksi kultur Braunschweig, Jerman yang diisolasi dari air laut di Hawaii, Amerika Serikat. Isolat XM26511 teridentifikasi sebagai Halomonas meridiana NBRC 15608 yang merupakan koleksi kultur NITE, Jepang. Mata, Martinez-Canovas, Quesada, dan Bejar (2002) melaporkan perbedaan fenotip secara umum di antara kedua spesies tersebut. $H$. aquamarina memiliki morfologi batang dan berwarna cream, sedangkan $\mathrm{H}$. meridiana berbentuk panjang dengan warna putih.

Isolat L15203 dan L16571 teridentifikasi sebagai spesies bakteri yang sama dengan derajat similaritas yang berbeda. Isolat L15203 memiliki similaritas 99\% dengan Idiomarina zobelli KMM 231, sedangkan similaritas L16571 sebesar 84\%. Derajat similaritas yang rendah dapat disebabkan oleh informasi genetis yang tidak lengkap atau termasuk dalam bakteri jenis baru, sehingga pengulangan analisis sebagian gen $16 \mathrm{~S}$ rDNA perlu dilakukan. Bakteri I. zobelli KMM 231 diisolasi dari kedalaman 4000-5000 m di barat laut Samudera Pasifik dan merupakan koleksi mikroorganisme laut Russian Academy of Sciences, Rusia. Ivanova et al. (2000) melaporkan bahwa I. zobelli KMM 231 merupakan bakteri aerob yang berukuran 0,7-0,9 $\mu \mathrm{m}$ dan dapat tumbuh pada kisaran konsentrasi $\mathrm{NaCl} 1-10 \%$.

Isolat X1654 memiliki kesamaan genetis sebesar 99\% dengan bakteri yang diisolasi dari air laut Hawaii, Amerika Serikat, Alteromonas macleodii NBRC 102226 yang merupakan koleksi NITE, Jepang (Anon., 2016). Menurut Lopez-Perez et al. (2012), A. macleodii merupakan bakteri laut Gammaproteobacteria yang terdistribusi luas di perairan tropis. Hal ini sesuai dengan kondisi perairan Indonesia yang terletak di daerah tropis.

Informasi genetis dari sebagian gen $16 \mathrm{~S}$ rDNA L22207 tidak selengkap isolat terpilih lainnya, sehingga dalam analisis molekuler diketahui similaritas isolat L22207 rendah, yaitu 78\% dengan Bacillus sp. MB 71. Bakteri Bacillus sp. MB 71 diisolasi dari sedimen laut pada kedalaman 1-3 m di Laut Kuning, Korea Selatan (Velmurugan et al., 2011). Meskipun demikian, rendahnya derajat similaritas juga dapat berarti kemungkinan ditemukannya bakteri jenis baru. Berdasarkan hal tersebut, pengulangan analisis molekuler untuk isolat L22207 perlu dilakukan untuk memastikan informasi genetik isolat L22207.

\section{KESIMPULAN}

Sebagian dari perairan Indonesia memiliki kelimpahan bakteri pendegradasi xilan dan manan penghasil xilanase netral dan alkali yang tahan pada suhu $70-90^{\circ} \mathrm{C}$ serta mananase alkali yang tahan suhu tinggi $\left(70-80^{\circ} \mathrm{C}\right)$. Jumlah isolat bakteri dari kedalaman $5 \mathrm{~m}$ yang diisolasi lebih banyak, yaitu 620 isolat, dibandingkan pada kedalaman $20 \mathrm{~m}$, yang berjumlah 537 isolat. Berdasarkan karakeristik aktivitas enzimnya, isolat bakteri XM26511 penghasil xilanase dan L22207 penghasil mananase merupakan isolat paling berpotensi untuk diteliti lebih lanjut.

\section{UCAPAN TERIMAKASIH}

Ucapan terimakasih penulis sampaikan kepada DIPA Tematik Pusat Penelitian Bioteknologi LIPI 2016 atas dukungan dana yang diberikan untuk penelitian ini. Sampel yang digunakan dalam penelitian ini merupakan sampel yang diambil pada bulan Agustus 2015 dalam Penelitian Lingkungan Geologi Perairan Laut Jawa, Laut Sulawesi Selatan hingga Sawu dengan menggunakan Kapal Riset Geomarin III (MAJAFLOTE). Penelitian tersebut merupakan kerjasama antara Pusat Penelitian dan Pengembangan Geologi Kelautan, Kementerian Energi dan Sumber Daya Mineral dengan Fakultas Perikanan dan Ilmu Kelautan, Institut Pertanian Bogor.

\section{DAFTAR PUSTAKA}

Andriana, S. E., Sudiana, I. M., \& Sembiring, L. (2009). Bakteri laut Pantai Sorong Papua Barat pendegradasi komponen crude oil. Prosiding Nasional Penelitian, Pendidikan, dan Penerapan MIPA, Yogyakarta, 148157.

Annamalai, N., Thavasi, R., Jayalakshmi, S., \& Balasubramanian, L. (2009). Thermostable and alkaline tolerant xylanase production by Bacillus subtilis isolated from marine environment. Indian J. Biotechnol., 8, 291-297.

Anonim.(2004).http://www.nbrc.nite.go.jp/NBRC2/NBRC CatalogueDetailServlet?ID=NBRC \&CAT $=00102226$. Anonim. (2016). https://blast.ncbi.nlm.nih.gov/Blast.cgi. Arahal, D. R., Ludwig, W., Schleifer, K. H., \& Ventosa, A. (2002). Phylogeny of the family Halomonadaceae based on $23 \mathrm{~S}$ and $16 \mathrm{~S}$ r DNA sequence analyses. Int. J. Syst. Evol. Microbiol., 52, 241-249.

Araujo, A., \& Ward, O. P. (1990). Purification and some properties of the mannanases from Thielavia terrestris. J Industr Microbiol, 6, 269-274.

Bahi, M. (2012)., Isolasi dan karakterisasi senyawa metabolit sekunder dari bakteri laut Streptomyces sp. Depik, 1(3), 161-164.

Bailey, M. J, Biely, P., \& Poutanen, K. (1992). Interlaboratory testing of methods for assay of xylanase activity. $J$ Biotechnol., 23, 257-270.

Beg, Q. K, Kapoor, M., Mahajan, L., \& Hoondal, G. S. (2001). Microbial xylanases and their industrial application: the review. Appl. Microbiol. Biotechnol., $56,326-338$. 
Blunt, J. W., Copp, B. R., Munro, M. H. G., Northcote, P. T., \& Prinsep, M. R. (2005). Marine natural products. Nat. Prod. Rep., 22, 15-61.

BPS. (2015). Luas kawasan hutan dan perairan. Diakses dari https://www.bps.go.id/.

Chauhan, P. S., Puri, N., Sharma, P., \& Gupta, N. (2012). Mannanase: microbial sources, production, properties, and potential biotechnological applications. Appl. Microbiol. Biotechnol., 93, 18171830.

Chen, C., Ko, T., Huang, J., \& Guo, R. (2015). Heat- and alkaline-stable xylanases: application, protein structure, and engineering. Chem. Bio. Eng. Rev., 2, 95-106.

Collins, T., Gerday, C., \& Feller, G. (2005). Xylanases, xylanase families and extremophilic xylanases. FEMS. Microbiol. Rev., 29, 3-23.

Comfort, D. A., Chhabra, S. R., Conners, S. B., Chou, C. Epting, K. L., Johnson, M. R., Jones, K. L., Sehgal, A. C., \& Kelly, R. M. (2004). Strategic biocatalysis with hyperthermophilic enzymes. Green Chem., 6, 459465.

Dhawan, S., \& Kaur, J. (2007). Microbial mannanases: an overview of production and applications. Crit. Rev. Biotechnol., 27, 197-216.

Djohan, A. C., Perwitasari, U., \& Yopi. (2016). Saccharification waste biomass rice straw IR-64 by using xylanase from indigenous marine bacteria Bacillus safensis LBF-002. Int. J. Adv. Sci. Eng. Inf. Technol., 6(1), 40-44.

Downie, B, Hilhorst, H. W. M., \& Bewley, J. D. (1994). A new assay for quantifying endo- $\alpha-D$-mannanase activity using congo red dye. Phytochemistry, 36, 829835.

Harwati, T. U., Kasai, Y., Kodama, Y., Susilaningsih, D., \& Watanabe, K. (2009). Tropicibacter naphthalenivorans gen. nov., sp. nov., a polycyclic aromatic hydrocarbon-degrading bacterium isolated from Semarang Port in Indonesia. Int. J. Syst. Evol. Microbiol., 59, 392-396.

Hatada, Y., Takeda, N., Hirasawa, K., Ohta, Y., Usami, R., Yoshida, Y., Grant, W. D., Ito, S., \& Horikoshi, K. (2005). Sequence of the gene for a high-alkaline mannanase from an alkaliphilic Bacillus sp. strain JAMB-750, its expression in Bacillus subtilis and characterization of the recombinant enzyme.

Khasin, A., Alchanati, I., \& Shoham, Y. (1993). Purification and characterization of a thermostable xylanase from Bacillus stearothermophilus T-6. Appl. Environ. Microbiol., 59, 1725-1730.

Ivanova, E. P., Romanenko, L. A., Chun, J., Matte, M. H., Matte, G. R., Mikhailov, V. V., Svetashev, V. I., Huq, A., Maugel, T., \& Colwell, R. R. (2000). Idiomarina gen. nov., comprising novel indigenous deep-sea bacteria from the Pacific Ocean, including descriptions of two species, Idiomarina abyssalis sp. nov. and Idiomarina zobelli sp. nov. Int. J. Syst. Evol. Microbiol., 50, 901-907.

Lopez-Perez., M, Gonzaga, A., Martin-Cuadrado, A., Onyshchenko, O., Ghavidel, A., Ghai, R., \& RodriguezValera, F. (2012). Genomes of surface isolates of
Alteromonas macleodii: the life of a widespread marine opportunistic copiotroph. Sci. Report, 2, 696.

Mata, J. A., Martinez-Canovas, J., Quesada, E., \& Bejar, V. (2002). A detailed phenotypic characterization of the strains of Halomonas species. System Appl. Microbiol., 25, 360-375.

McCleary, B. V. (1988). $\alpha$-D-Mannanase. Methods in Enzymology, 160, 596-610.

Menon, G., Mody, K., Keshri, J., \& Jha, B. (2010). Isolation, purification, and characterization of haloalkaline xylanase from a marine Bacillus pumilis GESF-1. Biotechnol. Biopro. Engineer., 15, 998-1005.

Miao, Y., Li, J., Xiao, Z., Shen, Q., \& Zhang, R. (2015). Characterization and identification of the xylanolytic enzymes from Aspergillus fumigatus Z5. BMC Microbiol., 15, 126.

Miller, G. L. (1959). Use of dinitrosalicylic acid reagent for determination of reducing sugar. Anal. Chem., 31, 426-428.

Muniarsih, T., \& Yopi. (2009). Isolasi, karakterisasi, dan potensi bakteri laut pendegradasi poliaromatik hidrokarbon asal pelabuhan Tanjung Mas Semarang. Jurnal Kelautan Nasional, 2, 95-100.

Muniarsih, T., Yopi, \& Budiawan. (2009). Biodegradasi fenantren oleh bakteri laut Pseudomonas $\mathrm{sp}$ KalP3b22 asal Kumai Kalimantan Tengah. Makara Sains, 13(1), 77-80.

Politz, O., Krah, M., Thomsen, K. K., \& Borriss,R. (2000). A highly thermostable endo-(1,4)- $\alpha$-mannanase from the marine bacterium Rhodothermus marinus. Appl. Microbiol. Biotechnol., 53, 715-721.

Pradeep, G. C., Cho, S. S., Choi, Y. S., Jee, J., Seong, C. N., \& Yoo, J.C. (2016). An extremely alkaline mannanase from Streptomyces sp. CS428 hydrolyzes galactomannan producing series of mannooligosaccharides. World J. Microbiol. Biotechnol., 32, 84.

Rahmani, N., Robbani, N. U. J., Suparto, I. H., \& Yopi. (2014). Optimization of production xylanase from marine bacterium Bacillus safensis P20 on sugarcane bagasse by submerged fermentation. Int J. Adv. Sci. Eng. Inf. Technol., 4(6), 31-34.

Sanders, H. W., \& Hessler, R. R. (1969). Ecology of the deep sea benthos. Science, 163, 1419-1424.

Scheffers, M., \& van Nes, E. H. (2007). Shallow lakes theory revisited: various alternative regimes driven by climate, nutrients, depth, and lake size. Hydrobiologia, 584, 455-466.

Sembiring, M., (2015). Prospek pengembangan bioteknologi kelautan dan perikanan. Diakses dari http://www.pusluh.kkp.go.id/arsip/.

Thomas, L., Sindhu, R., \& Pandey, A. (2013). Identification and characterization of a highly alkaline and thermotolerant novel xylanase from Streptomyces sp. Biologia, 68, 1022-1027.

Tork, S., Aly, M. M., Alakilli, S. Y., \& Al-Seeni, M. N. (2013). Production and characterization of thermostable xylanase from Bacillus subtilis XP10 isolated from marine water. Afr. J. Biotechnol., 12, 780-790. 
Velmurugan, N., Kalpana, D., Cho, J., Lee, G., Park, S., \& Lee, Y. (2011). Phylogenetic analysis of culturable marine bacteria in sediments from South Korean Yellow Sea. Microbiology+, 80, 261-272.

Winterhalter, C., \& Liebl, W. (1995). Two extremely thermostable xylanases of the hyperthermophilic bacterium Thermotoga maritima MSB8. Appl. Environ. Microbiol., 61, 1810-1815.

Wu, S., Liu, B., \& Zhang, X. (2006). Characterization of a recombinant thermostable xylanase from deep-sea thermophilic Geobacillus sp. MT-1 in East Pacific. Appl. Mlcrobiol. Biotechnol., 72, 1210-1216.

Yoo, H. Y., Pradeep, G. C., Kim, S. W., Park, D. H., Choi, Y. H., Suh, J. W., \& Yoo, J. C. (2015). A novel low- molecular weight alkaline mannanase from Streptomyces tendae. Biotechnol. Bioproc. Enginee., 20, 453-461.

Yopi, Susilaningsih, D., Thontowi, A., Purnawan, A., Djohan, A. C., Fahrurrozi, \& Lisdiyanti, P. (2007). Study on hemicellulolytic bacteria: production of oligosaccharides from palm kernel cake using fermentation. Prosiding dalam Seminar Internasional Advances in Biological Science: contribution towards a better human prosperity. UGM, 111-113.

Yopi, Djohan, A. C., \& Ambarsari, L. (2014). Mannanase from isolated marine bacteria of Pari Island for manno-oligosaccharides production. Prosiding dalam Asiahorcs 2013, 149-159. 
JPB Kelautan dan Perikanan Vol. 11 No. 1 Tahun 2016: 101-114 